Vol. 16(15), pp. 808-818, 12 April, 2017

DOI: 10.5897/AJB2017.15919

Article Number: CFAE43263694

ISSN 1684-5315

Copyright (C) 2017

African Journal of Biotechnology

Author(s) retain the copyright of this article

http://www.academicjournals.org/AJB

\title{
Determination of proximate and mineral compositions of Moringa oleifera and Moringa stenopetala leaves cultivated in Arbaminch Zuria and Konso, Ethiopia
}

\author{
Debebe Mikore and Eyobel Mulugeta* \\ Department of Chemistry, Ambo University, P. O. Box 19, Ambo, Ethiopia.
}

Received 28 January, 2017; Accepted 24 March, 2017

\begin{abstract}
This study presents the proximate and mineral composition analysis of Moringa oleifera and Moringa stenopetala leaves collected from two different agro-ecological zones namely Arbaminch Zuria and Konso in Southern Nation Nationalities and Peoples Region (SNNPR), Ethiopia. M. oleifera and $M$. stenopetala leaves were collected using random sampling method from four sampling sites namely Secha, Karat, Sikela, Gato. Before the samples were analyzed, parameters such as temperature, volume of reagents and time until complete digestion were systematically optimized. Analysis of variance was used to compare the proximate and elemental composition of leaf samples as well as mineral composition of soil. The results of this study revealed that, $M$. oleifera leaf samples from the Secha and Karat sampling sub-sites have shown the average moisture, ash, crude fiber, crude lipid and protein contents of $6.88 \pm 0.82,15.3 \pm 1.02,5.51 \pm 0.08,7.11 \pm 0.52,24.8 \pm 1.80 \%$ and $6.60 \pm 0.79,15.6 \pm 1.11,6.13 \pm 0.22$, $7.35 \pm 0.48,24.3 \pm 1.73 \%$, respectively. The average moisture, ash, crude fiber, crude lipid and protein contents of $7.92 \pm 0.85,14.9 \pm 0.93,5.03 \pm 0.12,3.65 \pm 0.11,27.3 \pm 2.10 \%$ and $7.73 \pm 0.96,14.1 \pm 0.87,5.87 \pm 0.21$, $4.29 \pm 0.12,30.2 \pm 2.61 \%$ were determined for $M$. stenopetala leaf samples from the Sikela and Gato, respectively. The contents of the nutrients found in Moringa leaves have shown no significant differences from the two agro-ecological zones except some nutrients (ash, lipid, and protein). The K, $\mathrm{Na}, \mathrm{Mg}, \mathrm{Ca}, \mathrm{Mn}, \mathrm{Zn}, \mathrm{Fe}$, and $\mathrm{Cu}$ concentration determined from Moringa leaf samples from the two agroecological zones was ranged between 9570-14047, 1287-1298, 4273-4550, 18230-19026, 72.4-87.5, 21.357.6, 80.1-82.3 and $3.43-5.10 \mathrm{mg} / \mathrm{Kg}$, respectively. The comparison of mean values of macro and micro nutrient of Moringa leaves and soils showed no significant difference between the two agro-ecological zones except some metals such as $\mathrm{K}, \mathrm{Zn}$ and $\mathrm{Cu}$. The present analysis revealed that Moringa leaves contained considerable amount of nutrients and hence used as food supplement for the community.
\end{abstract}

Key words: Nutritional compositions, elemental composition, Moringa species, agro-ecological zones, proximate analysis.

\section{INTRODUCTION}

In Africa, many studies have indicated that a vast number of indigenous wild plants play a significant role in the diet of the population (Muhammad et al., 2011). Vegetables are the cheapest and the most available sources of important nutrients, supplying the body with minerals, salts, vitamins and certain hormone precursors, protein, 
energy and essential amino acids (Amaechi, 2009).

$M$. oleifera and $M$. stenopetala are the two most common species among the 13 species of the Moringa family. $M$. oleifera originates from the Himalaya and $M$. stenopetala is endemic to East Africa (Bosch, 2004). All parts of the tree except the wood are edible, providing a highly nutritious food for both humans and animals. $M$. stenopetala is one of the most frequently cultivated indigenous species for its palatable leaves in the semiarid areas of Konso, Derashe and Arbaminch Zuria districts of the Southern Rift Valley of Ethiopia and locally called as "Haleko" or "Shiferaw". It is also cultivated from the lower Omo Valley to the North and in the neighboring regions of South Omo, Gamo-Gofa and Borena (Grubben and Denton, 2004).

Moringa is a multi-purpose miracle tree with tremendous potential uses such as food for human beings, feed for livestock, dye, perfume, skin lotion, lubricant and water purification (Agena, 2009). The Moringa leaves are nutritionally rich and an excellent source of concentrated proteins, vitamins and minerals (Armelle and Melanie, 2010). It has also potential medicinal uses such as: the root bark is being used to kill different kinds of intestinal worms, increases food appetite, protect abdominal constipation, cure for different kinds of respiratory diseases such as bronchitis and influenza and the stem bark is being used to treat eye diseases, intestinal worms, and to decrease or neutralize the venom power of snake, bee and scorpion (Grubben and Denton, 2004).

A recent study conducted by Melesse et al. (2009) indicated that the leaves of Moringa stenopetala are rich in protein $(28.2 \%)$ and contain reasonable amounts of essential amino acids of which some are comparable with those found in soybean meal. It is a multipurpose tree that is cultivated both for human food and animal feed in Southern Ethiopia. Moringa leaves have been consumed by Asian people for millennia as a healthy food product. Studies from other countries indicate that the leaves have immense nutritional value such as phytochemicals, vitamins, minerals, and amino acids (Busani et al., 2011). As such, the leaves have been used to combat malnutrition, especially among infants and nursing mothers. The Romans, Greeks, and Egyptians extracted edible oil from the seeds and used it for perfume and as a skin lotion. People in the Indian subcontinent have long used Moringa pods for food. The edible leaves are eaten throughout East Africa and parts of Asia. Moringa leaves are edible and are of high nutritive value (Tetteh, 2008). It has been reported that $M$. oleifera leaves product, especially leaf powder, is becoming increasingly popular in Ethiopia because of its outstanding indigenous nutritive and medicinal value. The leaves are also free of anti- nutritive factors such as phenols, tannins, and saponins (ljarotimi et al., 2013).

In many developing countries, the supply of minerals is inadequate to meet the mineral requirements of farm animals and rapidly growing population. Mineral composition of a plant plays significant role its nutritional, medicinal and therapeutic values (Al-Kharusi et al., 2009).

$M$. oleifera contains several elements which are the basic building block of matter. Some of the elements are calcium, magnesium, potassium, sodium and the minor elements are iron, zinc, copper and manganese (Melesse and Berihun, 2013). However, complete information on the nutritional compositions of main edible parts of both Moringa species, that is, leaves cultivated in different agro-ecological zones of southern Ethiopia is still scarce. Therefore, the objectives of this study are: (1) to investigate the effect of agro-ecological variations in nutritional levels of leaves in Moringa species (2) to assess the nutritional levels of leaves in the two Moringa species in comparison with similar studies (3) to compare the proximate compositions in the leaves powder of $M$. oleifera and $M$. stenopetala grown in two different agroecological zones (4) to optimize the sample digestion method for both leaf and soil samples; and (5) to investigate and compare the elemental compositions of leaves powder of $M$. oleifera and $M$. stenopetala and the supporting soils in two different agro-ecologic zones..

\section{MATERIALS AND METHODS}

\section{Description of the study area}

The study was conducted in Arbaminch Zuria and Konso districts of SNNPR, Ethiopia. Arbaminch Zuria district is located at $6^{\circ} 01^{\prime} 59^{\prime \prime} \mathrm{N}$ and $37^{\circ} 32^{\prime} 59^{\prime \prime} \mathrm{E}$, altitude of 1269 m.a.s.l and $505 \mathrm{~km}$ away from the capital city, Addis Ababa. Konso district is located at $5^{\circ} 15^{\prime} 00^{\prime \prime} \mathrm{N}$ and $37^{\circ} 28^{\prime} 59^{\prime \prime} \mathrm{E}$ and altitude of $1031 \mathrm{~m}$.a.s.I. It is $536 \mathrm{Km}$ far from Addis Ababa. Four sampling sub-sites (that is, two from each district) were selected, namely Secha and Sikela from Arbaminch Zuria and Karat and Gato from Konso district.

\section{Chemicals and reagents}

All chemicals and reagents were of analytical reagent grade and obtained from Ambo University Chemistry Laboratory. Acid washed glassware and deionized water were used throughout the analysis.

\section{Sampling protocol}

\section{Leaf samples}

Samples of fresh Moringa leaves were collected from matured $M$. oleifera from Secha and Karat and M. stenopetala from Sikela and

*Corresponding author. E-mail: eyoya2004@yahoo.com. Tel: +251911488053.

Author(s) agree that this article remains permanently open access under the terms of the Creative Commons Attribution License 4.0 International License 
Gato sub-sites. Each sample was collected randomly from ten trees in each sampling sub-sites. About $500 \mathrm{~g}$ of the samples were collected from each agro-ecological zone and was placed in polyethylene plastic bags, labeled and transported to the laboratory for further treatment.

\section{Soil samples}

Soil samples were collected from the surface soil layers with a depth of about 0 to $15 \mathrm{~cm}$ at the point where Moringa leaves plugged. About $500 \mathrm{~g}$ of soil samples were collected from each subsite into polyethylene plastic bags, labeled and transported to the laboratory for further treatment.

\section{Sample preparation}

\section{Leaf samples}

The leaves were washed with deionized water to remove dust materials and air dried in shade for two weeks to ensure their greenish coloration and maintain nutritional values. The dried leaves were milled and sieved with $0.5 \mathrm{~mm}$ sieve. The powders were packaged into polyethylene bags, labeled and stored at room temperature $\left(24 \pm 3{ }^{\circ} \mathrm{C}\right)$ prior to analysis.

\section{Soil samples}

The samples were air dried to constant weight for two weeks, grinded using mortar and pestle, sieved through a $0.5 \mathrm{~mm}$ stainless steel sieve and labeled. Finally, $0.5 \mathrm{~g}$ aliquot was taken from each sample for digestion.

\section{Proximate composition analysis}

Moisture content, total ash content, crude lipid content, and crude protein content were determined using AOAC methods as determined from (AOAC, 1990) and (AOAC, 2000) using AOAC 900.02A and AOAC 978.04 methods.

\section{Moisture content}

Moisture content was determined on dry basis. From each site, $2 \mathrm{~g}$ of Moringa leaf samples were weighed in triplicates and placed in an oven (Tianjin Taisite instrument, $101-0$, China) at $105^{\circ} \mathrm{C}$ for $3 \mathrm{~h}$. The samples were removed and cooled in desiccators. Then the dried samples were reweighed. The percentage moisture was calculated as follows:

Moisture content percentage $(\%)=\frac{\left(w_{1}-w_{2}\right)}{w_{1}} \times 100$

$W_{1}=$ Weight of air dried leaves; $W_{2}=$ weight of oven dried leaves.

\section{Total ash content}

Total ash content was determined using AOAC 900.02A method as described in (AOAC, 1990). About $2.0 \mathrm{~g}$ of leaf samples from each site were weighed in triplicates. Dried and powdered samples were incinerated in a muffle furnace at $550^{\circ} \mathrm{C}$ for $4 \mathrm{~h}$, cooled in desiccators and weighed until the weight is constant.

Total ash $(\%)=\frac{\text { Weight of ash }}{\text { Initial weight of sample }} \times 100$

\section{Crude fiber content}

After introducing $2.0 \mathrm{~g}$ sample into the extraction unit, $150 \mathrm{~mL}$ of hot $0.2 \mathrm{~N} \mathrm{H}_{2} \mathrm{SO}_{4}$ was added and digested for $30 \mathrm{~min}$. Then, the acid was drained and the sample was washed with hot deionized water for 1 h. The crucible was removed and oven dried overnight at $105^{\circ} \mathrm{C}$, cooled, weighed, and heated at $550^{\circ} \mathrm{C}$ in a muffle furnace overnight and reweighed after cooling. Percentage extracted fiber was calculated as:

Crude fiber $(\%)=\frac{\text { Weight of digested sample-Weight of ashed sample }}{\text { Weight of samples }} \times 100$

\section{Crude lipids content}

The lipid content was determined as the weight change recorded after exhaustively extracting a food substance with a non-polar solvent using Soxhlet method and petroleum ether according to AOAC 945.16 method as described in (AOAC, 1990). The solute was separated from the solvent by evaporation of the solvent leaving the extracted lipid. Weight of the solvent flask with lipid was taken. In the present study, $2.0 \mathrm{~g}$ of leaf samples from each site were weighed in triplicates. The Soxhlet apparatus was set-up and the samples were extracted with $200 \mathrm{~mL}$ of petroleum ether for $6 \mathrm{~h}$. The solvent free fat in the flux was dried in an oven for an hour at $105^{\circ} \mathrm{C}$, cooled in desiccators and reweighed until the weight is constant.

$$
\text { Crude lipid }(\%)=\frac{(\text { Weight of extract }+ \text { Weight of flux }- \text { Weight of flux })}{\text { Initial weight of sample }} \times 100
$$

\section{Crude protein content}

Crude protein was determined using AOAC 978.04 method as described in (AOAC, 2000). It is a micro Kjeldahl method. In the present study, about $2.0 \mathrm{~g}$ of leaf samples from each site were weighed in triplicates. Then, $10 \mathrm{~mL}$ of concentrated $\mathrm{H}_{2} \mathrm{SO}_{4}$, a mixture of $2.5 \mathrm{~g}$ of $\mathrm{CuSO}_{4}, \mathrm{~K}_{2} \mathrm{SO}_{4}$ and $\mathrm{TiO}_{2}$ were added into each sample and digested in a Kjeldahl digestion flask (KDN-20C, China) at $380^{\circ} \mathrm{C}$ for $6 \mathrm{~h}$ until the mixture was clear. The digest was filtered into $500 \mathrm{~mL}$ volumetric flask and made up to mark with $100 \mathrm{~mL}$ deionized water and connected for distillation. Ammonia was steam distilled for an hour to which had been added $20 \mathrm{~mL}$ of $40 \% \mathrm{NaOH}$ solution. Two hundred milliliters of the distillate was collected in 250 $\mathrm{mL}$ conical flask containing $20 \mathrm{~mL}$ of $0.2 \mathrm{~N} \mathrm{H}_{2} \mathrm{SO}_{4}$ and methyl red indicator.

The ammonia that distilled into the receiving conical flask was reacted with $0.2 \mathrm{~N} \mathrm{H}_{2} \mathrm{SO}_{4}$ and the excess acid in the flask was estimated by back titration against $20 \mathrm{~mL}$ of $0.1 \mathrm{~N} \mathrm{NaOH}$ with color change from red to yellow. A blank distilled was collected in $250 \mathrm{~mL}$ conical flask containing $20 \mathrm{~mL}$ of $0.2 \mathrm{~N} \mathrm{H}_{2} \mathrm{SO}_{4}$ and methyl red indicator. The distillate was titrated against $20 \mathrm{~mL}$ of $0.1 \mathrm{~N} \mathrm{NaOH}$. Total nitrogen in the sample was calculated using colorimetric methods (Nielson, 2010). Crude protein content was obtained by multiplying the nitrogen content using factor 6.25 , that is, $\mathrm{N} \times 6.25$ (James, 1995).

\section{Carbohydrate}

The carbohydrate content was determined by difference, that is, addition of all the percentages of moisture, ash, crude lipid, crude protein, and crude fiber was subtracted from $100 \%$. This gave the amount of nitrogen-free extract otherwise known as carbohydrate (Mahan et al., 2016). 
Table 1. Proximate compositions of Moringa oleifera and Moringa stenopetala leaf powder (\% Dry weight basis).

\begin{tabular}{llccccc}
\hline Sub-site & Sample type & Moisture (\%) & Ash (\%) & Crude fiber (\%) & Crude lipid (\%) & Crude protein (\%) \\
\hline Secha & M. oleifera & $6.88 \pm 0.82$ & $15.3 \pm 1.02$ & $5.51 \pm 0.08$ & $7.11 \pm 0.52$ & $24.8 \pm 1.80$ \\
Sikela & M. stenopetala & $7.92 \pm 0.85$ & $14.9 \pm 0.93$ & $5.03 \pm 0.12$ & $3.65 \pm 0.11$ & $27.3 \pm 2.10$ \\
Karat & M. oleifera & $6.60 \pm 0.79$ & $15.6 \pm 1.11$ & $6.13 \pm 0.22$ & $7.35 \pm 0.48$ & $24.3 \pm 1.73$ \\
Gato & M. stenopetala & $7.73 \pm 0.96$ & $14.1 \pm 0.87$ & $5.87 \pm 0.21$ & $4.29 \pm 0.12$ & $30.2 \pm 2.61$ \\
\hline
\end{tabular}

$\%$ Carbohydrate $=100-\left(\begin{array}{c}\% \text { Moisture }+\% \text { Ash }+\% \text { Crude lipid }+ \\ \% \text { Crude protein }+\% \text { Crude fiber }\end{array}\right)$

\section{Energy value}

The sample energy value was estimated (in $\mathrm{kcal} / \mathrm{g}$ ) by multiplying the percentages of crude protein, crude lipid, and carbohydrate with the recommended factors $(2.44,8.37$, and 3.57 respectively) as proposed by Martin and Coolidge (1978).

\section{Determination of soil pH}

A pH glass electrode (Elmetron ${ }^{\circledR}$ EPSI-1, Poland) was used to determine the soil $\mathrm{pH}$. Soil $\mathrm{pH}$ was measured in soil-water slurry. The determination of the soil $\mathrm{pH}$ is a three-step procedure: First the soil-water slurry in the ratio 1:5 was prepared. Air dried soil of $10 \mathrm{~g}$ was taken in a beaker and $50 \mathrm{~mL}$ of water was added. The mixture was stirred with glass rod for $15 \mathrm{~min}$, and allowed to stand for 30 min. Secondly, the $\mathrm{pH}$ meter was calibrated with a buffer solutions of $\mathrm{pH}$ of 4.0, 7.0 and 9.0. Finally, the electrode was immersed into soil-water slurry and the $\mathrm{pH}$ was recorded.

\section{Optimization of sample digestion}

Sample digestion was carried out using wet digestion with a reflux condenser for both leaf and soil samples. The reagents used were mixture of nitric acid, perchloric acid and hydrogen peroxide. Before the samples were digested for analysis the parameters such as temperature, volume of reagents and time for complete digestion were carefully optimized. The optimum condition is one that meets: Minimum reagent volume, temperature, and digestion time to produce a clear and colorless digested solution.

\section{Wet digestion method}

Approximately $0.5 \mathrm{~g}$ of each of sample leaves was weighed in triplicate. Two milliliters of concentrated $\mathrm{HNO}_{3}, 1 \mathrm{~mL}$ of concentrated $\mathrm{HClO}_{4}$ and $1 \mathrm{~mL}$ of $\mathrm{H}_{2} \mathrm{O}_{2}$, added to leaf samples and digested at a temperature of $210^{\circ} \mathrm{C}$ for $2 \mathrm{~h}$. Similarly for soil samples, $6 \mathrm{~mL}$ of concentrated $\mathrm{HNO}_{3}, 1 \mathrm{~mL}$ of concentrated $\mathrm{HClO}_{4}$ and $0.5 \mathrm{~mL}$ of $\mathrm{H}_{2} \mathrm{O}_{2}$ were added and digested at a temperature of $230^{\circ} \mathrm{C}$ for $2.5 \mathrm{~h}$.

\section{Determination of minerals}

Flame atomic emission spectrophotometer (FAES, ELICO-CL-378, India) was used for analysis of $\mathrm{K}$ and $\mathrm{Na}$. Working standard solutions of $\mathrm{Mn}, \mathrm{Fe}, \mathrm{Zn}$ and $\mathrm{Cu}$ were prepared from stock standard solution (1000 ppm) and absorbance was noted from standard solution of each element using flame atomic absorption spectrophotometer (FAAS, Model 210-VGP, USA). The concentrations of $\mathrm{Ca}$ and $\mathrm{Mg}$ were determined by back titration against $\mathrm{MgCl}_{2} \cdot 6 \mathrm{H}_{2} \mathrm{O}$ and $\mathrm{CaCl}_{2} \cdot 2 \mathrm{H}_{2} \mathrm{O}$.

\section{Statistical analysis}

Each experimental analysis was done in triplicate. Data obtained from experiments were analyzed by one way ANOVA (Analysis of Variance) using SPSS version 17. Significance was accepted at 0.05 level of probability $(p<0.05)$. The analysis was used to compare the proximate and elemental composition of leaf samples of Moringa species as well as mineral composition of soil collected from two different agro-ecological zones.

\section{RESULTS AND DISCUSSION}

\section{Proximate composition}

\section{M. oleifera leaves powder from Secha and Karat}

The proximate compositions of $M$. oleifera and $M$. stenopetala leaves powder are presented in Table 1. As indicated in Table 1, the average moisture content range between 6.88 and $6.60 \%$ in Moringa oleifera leaves powder. The higher moisture content was recorded for the Secha $M$. oleifera leaf samples $(6.88 \%)$ and the lower moisture content for Karat $(6.60 \%)$. There was no significant difference in moisture contents of Moringa oleifera leaf samples $(P>0.05)$ from the two agroecological zones. The moisture content $(6.88 \%)$ which was recorded from Secha $M$. oleifera was slightly higher than that of similar researches with moisture content values of $3.21 \%$ (Anthonia, 2012). Other studies have reported variable moisture contents ranging between 9.53 and $11.76 \%$ which was relatively higher than this study (Ogbe and John, 2011; Busani et al., 2011).

The total ash content ranged between 15.30 and $15.60 \%$. The higher ash content was recorded for the Karat $M$. oleifera leaves powder $(15.60 \%)$ and the lower ash content for the Secha M. oleifera leaves (15.30\%). There was no significant difference in ash contents of $M$. oleifera leaf samples $(P>0.05)$ from the two agroecological zones. The ash content $(15.60 \%)$, which was recorded from Karat $M$. oleifera leaves powder, was comparatively higher when compared to values obtained from similar research with ash content values of 7.13 and 
$10.6 \%$, respectively (Onu and Aniebo, 2011; Busani et al., 2011). Thus, the result indicated that $M$. oleifera leaves collected from the two agro-ecological zones were rich in mineral elements.

Crude fiber of the $M$. oleifera leaves powder ranged from 5.51 to $6.13 \%$. Higher crude fiber $(6.13 \%)$ was recorded from Karat site and lower $5.51 \%$ was recorded from Secha site. There was no significant difference in crude fiber content of $M$. oleifera leaf samples $(P>0.05)$ from the two agro-ecological zones. The fiber content of $M$. oleifera leaves powder was quite low when compared with similar data reported by ljarotimi et al. (2013). Dietary fiber, the indigestible cell wall component of plant materials, plays an important role in human health (Wani et al., 2014). Epidemiological studies have shown that high dietary fiber intake helps to prevent or treat hyperlipidemia, cardiovascular disease, hypertension, obesity, certain cancers, gastrointestinal disorders and diabetes (ljarotimi et al., 2013).

The crude lipid content of $M$. oleifera leaves powder from Secha and Karat was 7.11 and $7.35 \%$, respectively. The higher lipid content was recorded for the Karat $M$. oleifera leaf samples $(7.35 \%)$ and the lower lipid content for the Secha leaf samples $(7.11 \%)$. There was no significant difference in crude lipid contents of $M$. oleifera leaf samples $(P>0.05)$ from the two agro-ecological zones. The crude lipid $(7.35 \%)$, which was recorded from Karat $M$. oleifera leaf samples, was comparatively higher compared to values obtained in similar research with crude lipid content values of $6.73 \%$ (Melesse et al., 2011).

The crude protein contents from the Secha and Karat M. oleifera leaves powder were 24.80 and $24.30 \%$, respectively. The higher crude protein content was recorded for the Secha M. oleifera leaf samples (24.80\%) and the lower crude protein content for the Karat leaf samples $(24.30 \%)$. There was no significant difference in crude protein contents of $M$. oleifera leaf samples $(P>$ $0.05)$ from the two agro-ecological zones. The results indicated that $M$. oleifera leaves from the Secha contained appreciable amount of crude protein content $(24.80 \%)$ and was comparatively higher than that of similar studies (Sanchez et al., 2006) for the same Moringa species (22.8\%). Other studies have reported variable protein contents ranging between 16 and $40 \%$ (Shad et al., 2016; Sanchez-Machado et al., 2010). This level of crude protein content is of particular nutritional significance as it may meet animal's protein and energy requirements and boost the immune system against disease (Melesse et al., 2012).

\section{M. stenopetala leaves powder from Sikela and Gato}

As indicated in Table1, the moisture contents of $M$. stenopetala leaves powder ranges between 7.92 and $7.73 \%$. The result of the study indicated that dried
Moringa stenopetala leaves from the Sikela contained higher moisture content $(7.92 \%)$ and the lower moisture content was recorded from Gato leaf samples (7.73\%). There was no significant difference in moisture contents of $M$. stenopetala leave samples $(P>0.05)$ from the two agro-ecological zones.

The total ash contents of $M$. stenopetala leaves powder ranges between 14.90 and $14.10 \%$. The higher ash content was recorded from Sikela $M$. stenopetala leaf samples (14.90\%) and the lower ash content from Gato leaf samples (14.10\%). There was no significant difference in ash contents of $M$. stenopetala leaf samples $(\mathrm{P}>0.05)$ from the two ecological zones. High ash content of $(14.90 \%)$ from the Sikela $M$. stenopetala leaves powder in this study was comparable with that of similar study (Melesse et al., 2011) for the same Moringa species was found to be $14.80 \%$.

Crude fiber of the $M$. stenopetala leaves powder ranged from 5.03 to $5.87 \%$. Higher crude fiber $(5.87 \%)$ was recorded from Gato site and lower $5.03 \%$ was recorded from Sikela site. There was no significant difference in ash contents of $M$. stenopetala leaf samples $(P>0.05)$ from the two agro-ecological zones. The fiber content of $M$. stenopetala leaves powder was quite low when compared with similar data reported by ljarotimi et al. (2013).

The crude lipid contents for $M$. stenopetala leaves powder ranges between 3.65 and $4.29 \%$. The higher crude lipid content was recorded for the Gato $M$. stenopetala leaf samples (4.29\%) and the lower crude lipid content for the Sikela leaf samples (3.65\%). There was no significant difference in crude lipid contents of $M$. stenopetala leaf samples $(P>0.05)$ from the two ecological zones. The average crude lipid content in $M$. stenopetala leaf samples from the Gato $(4.29 \%)$ was comparatively higher than that of related study (Melesse et al., 2011) for the same Moringa species found (3.36\%).

The crude protein content of $M$. stenopetala leaves powder ranges between 27.30 and $30.20 \%$. The higher crude protein content was recorded for the Gato $M$. stenopetala leaf samples (30.20\%) and the lower crude protein content for the Sikela leaf samples (27.30\%). There was no significant difference in crude protein contents of $M$. stenopetala leaf samples $(P<0.05)$ from the two agro-ecological zones. The average crude protein content in $M$. stenopetala leaf samples from the Gato $(30.20 \%)$ was comparatively higher than that of similar study (Melesse et al., 2011) for the same Moringa species found $26.6 \%$.

All in all, there was no as such significant difference in nutritional composition of the two Moringa species grown in the two agro-ecological zones; this might be due to the lesser effect of variation in agro-ecological zones on compositions of nutrition of Moringa species. Therefore, other factors such as age, maturity of Moringa trees, soil conditions and so on might plays a major role in variation of nutritional as well as mineral composition of the species. 
In addition, the proximate compositions of the two species have shown increment in their levels as compared with similar studies; in particular, the moisture content of the leaves was relatively lower and depicted higher values for the rest of proximate compositions (ash content, crude lipid, and crude fiber) in an indirect relationship as it decreases.

\section{M. oleifera and M. stenopetala leaves powder from Secha and Sikela}

As indicated in Table 1, the moisture contents of $M$. oleifera leaves powder from Secha was $6.88 \%$ and $M$. stenopetala leaves from the Sikela contained moisture content of $7.92 \%$. Higher moisture content was recorded for the Sikela M. stenopetala leaf samples (7.92\%). There was no significant difference in moisture contents of the two species $(P>0.05)$ with in the same agro-ecological zones.

The total ash contents of $M$. oleifera leave powder from Secha $15.30 \%$. The lower ash content was recorded for the Sikela M. stenopetala leaf sample (14.90\%). There was no significant difference in ash contents of the two leaf samples $(P>0.05)$ with in the same agro-ecological zones. High ash content of (15.30\%) from the Secha $M$. oleifera leaves powder in this study was comparatively higher when compared to related study for the same Moringa species (13.20\%). However, the ash content of M. stenopetala leaves from the Sikela was comparable for the same Moringa species which was found to be $14.60 \%$ (Melesse et al., 2012).

The crude fiber contents of $M$. oleifera leave powder from Secha $5.51 \%$. The crude fiber content was recorded for the Sikela M. stenopetala leaf samples $(5.03 \%)$. There was no significant difference in crude fiber contents of the two leaf samples $(P>0.05)$ with in the same agroecological zones.

The crude lipid contents for $M$. oleifera leaves powder from the Secha was $7.11 \%$ and the lower crude lipid content was recorded for the Sikela $M$. stenopetala leaf samples (3.65\%). There was significant difference in crude lipid contents of the two species $(P<0.05)$ with in the same agro-ecological zones. The average crude lipid content in $M$. oleifera leaf samples from the Secha (7.11\%) was comparatively lower compared to similar study for the same Moringa species found (10.40\%). However, the crude lipid content of $M$. stenopetala leaves from the Sikela $(3.65 \%)$ was comparatively lower than that of similar study for the same Moringa species was found to be $10.70 \%$ (Melesse et al., 2012).

The crude protein content of $M$. oleifera leaves powder from the Secha was $24.80 \%$. The higher crude protein content was recorded for the Sikela $M$. stenopetala leaves sample (27.30\%). There was no significant difference in crude protein contents of the two species $(P$ $>0.05)$ with in the same agro-ecological zones. The average crude protein content in $M$. oleifera leaf samples from the Secha $(24.80 \%)$ was comparatively lower than the related study for the same Moringa species found $29.0 \%$ (Melesse et al., 2012).

\section{M. oleifera and M. stenopetala leaves powder from Karat and Gato}

As indicated in Table 1, the moisture content for the Karat $M$. oleifera leaf samples were $(6.60 \%)$ and $M$. stenopetala leaves from the Gato contained moisture content of $(7.73 \%)$. Higher moisture content was recorded from Gato M. stenopetala leaf samples (7.73\%). There was no significant difference in moisture contents of the two species $(P>0.05)$ with in the same agroecological zones.

The total ash contents of $M$. oleifera leaves powder from the Karat was $15.60 \%$. The lower ash content was recorded from Gato $M$. stenopetala leaf samples $(14.10 \%)$. There was significant difference in ash contents of the two species $(P<0.05)$ with in the same agro-ecological zones. High ash content of (15.60\%) from the Karat $M$. oleifera leaves powder in this study was comparatively higher than that of for the same Moringa species was found to be $13.20 \%$. However, the ash content of $M$. stenopetala leaves from the Gato (14.10\%) was comparable from similar study for the same Moringa species was found to be $14.60 \%$ (Melesse et al., 2012).

The crude fiber contents of $M$. oleifera leaves powder from Karat was $6.13 \%$. The lower crude fiber content was recorded from Gato M. stenopetala leaf samples (5.87\%). There was no significant difference in crude fiber contents of the two leaf samples $(P>0.05)$ with in the same agro-ecological zones.

The crude lipid contents for $M$. oleifera leaves powder from the Karat was $7.35 \%$. Lower crude lipid content was recorded for the Gato $M$. stenopetala leaf samples $(4.29 \%)$. There was significant difference in crude lipid contents of the two species $(P<0.05)$ with in the same agro-ecological zones. The average crude lipid content in M. oleifera leaf samples from the Karat $(7.35 \%)$ was comparatively lower than that of related study for the same Moringa species found (10.4\%). However, the crude lipid content of $M$. stenopetala leaves from the Gato $(14.10 \%)$ was comparable to similar study for the same Moringa species was found to be $14.60 \%$ (Melesse et al., 2012).

The crude protein content of $M$. oleifera leaves powder from the Karat was $24.30 \%$. Higher crude protein content was recorded for the Gato M. stenopetala leaf samples $(30.20 \%)$. There was significant difference in crude protein contents of the two species $(P<0.05)$ with in the same agro-ecological zones. The average crude protein content in $M$. oleifera leaf samples from the Karat $(24.30 \%)$ was comparatively lower than related study for the same Moringa species found (29.0\%). However, the crude protein content of $M$. stenopetala leaves from the Gato $(30.20 \%)$ was comparatively higher than that of 
Table 2. Calculated carbohydrate and energy value of Moringa oleifera and Moringa stenopetala leafves powder from two different agro-ecological zones.

\begin{tabular}{llcc}
\hline Sub-site & Sample type & Carbohydrate $(\%)$ & Energy value (kcal/g) \\
\hline Secha & M. oleifera & $40.4 \pm 3.21$ & $264.3 \pm 5.23$ \\
Sikela & M. stenopetala & $41.2 \pm 2.89$ & $244.2 \pm 4.41$ \\
Karat & M. oleifera & $40.0 \pm 2.76$ & $263.7 \pm 6.01$ \\
Gato & M. stenopetala & $37.8 \pm 2.53$ & $244.6 \pm 3.96$ \\
\hline
\end{tabular}

Table 3. Concentration (mean $\pm \mathrm{SD}, \mathrm{n}=3, \mathrm{mg} / \mathrm{kg}$ air dry weight) of metals in $M$. oliefera and $M$. stenopetala leaf samples.

\begin{tabular}{cccccc}
\hline \multirow{2}{*}{ Metals } & \multicolumn{4}{c}{ Metal concentration $\mathbf{( m g / k g )}$} & \multirow{2}{*}{$\begin{array}{c}\text { WHO permissible } \\
\text { limit (mg/kg) }\end{array}$} \\
\cline { 2 - 4 } & Secha & Karat & Sikela & Gato & \\
\cline { 2 - 4 } & M. oleifera & M. oleifera & M. stenopetala & M. stenopetala & \\
K & $12160 \pm 779.70$ & $9570 \pm 21.0$ & $12247 \pm 434.90$ & $14047 \pm 97.14$ & Not specified \\
$\mathrm{Na}$ & $1296 \pm 101.5$ & $1287 \pm 108.1$ & $1293 \pm 99.02$ & $1298 \pm 99.50$ & Not specified \\
$\mathrm{Mg}$ & $4370 \pm 120.0$ & $4273.3 \pm 215.0$ & $4550 \pm 310.5$ & $4500 \pm 242.7$ & Not specified \\
$\mathrm{Ca}$ & $19026 \pm 648.30$ & $18803 \pm 114.0$ & $18342 \pm 1010.0$ & $18230 \pm 990.2$ & Not specified \\
$\mathrm{Mn}$ & $72.37 \pm 3.37$ & $76.77 \pm 0.85$ & $86.13 \pm 2.19$ & $87.53 \pm 1.40$ & $2.0^{\mathrm{b}}$ \\
$\mathrm{Zn}$ & $31.87 \pm 2.11$ & $21.30 \pm 2.09$ & $57.63 \pm 4.45$ & $27.90 \pm 1.59$ & $27.4^{\mathrm{b}}$ \\
$\mathrm{Fe}$ & $81.60 \pm 1.14$ & $81.37 \pm 2.11$ & $80.03 \pm 2.50$ & $82.30 \pm 2.65$ & $20.0^{\mathrm{b}}$ \\
$\mathrm{Cu}$ & $5.10 \pm 0.20$ & $3.90 \pm 0.53$ & $3.43 \pm 0.15$ & $4.13 \pm 0.15$ & $3.0^{\mathrm{b}}$ \\
\hline
\end{tabular}

bsource: FAO/WHO (2001).

related study for the same Moringa species was found to be $28.0 \%$ (Melesse et al., 2012).

The variations in ash, crude lipid and protein contents of the reported values may be due to different ages of trees, and possibly due to different stages of maturity (Yang et al., 2006).

\section{Carbohydrate and energy values}

The calculated carbohydrate and energy values for $M$. oleifera and $M$. stenopetala leaves powder collected from the four sub-sites were reported in Table 2. The \%carbohydrate of Moringa species from Sikela, Secha, Karat and Gato were calculated using Equation 5 and found to be $40.4,41.2,40.0$ and 37.8 , respectively. There was no significant difference in \%carbohydrate of $M$. stenopetala and $M$. oleifera leave samples $(P>0.05)$ from the two agro-ecological zones. The energy value $(\mathrm{kcal} / \mathrm{g})$ of Moringa leaves were also calculated as 264.3 (Secha), 244.2 (Sikela), 263.7 (Karat) and 244.6 (Gato). The result of energy value calculated for both Moringa species were found to be lower than related studies (Melesse et al., 2011).

\section{Elemental compositions of Moringa species}

\section{Metal levels in the M. oliefera leaf samples from Secha and Karat}

As shown in Table 3, the mean potassium concentration in the M. oliefera leaves samples were 12160 and 9570 $\mathrm{mg} / \mathrm{kg}$ for Secha and Karat, respectively. There were significant differences at $(P<0.05)$ among the mean concentrations of $\mathrm{K}$ metal in the leaf samples. These differences could probably be the result of plant nutrition, climate and soil conditions (Hamurcu et al., 2010).

The sodium concentration of the $M$. oliefera leaf samples analyzed (Table 3) were 1296 and $1287 \mathrm{mg} / \mathrm{kg}$ for Secha and Karat, respectively. F-test showed that there were no significant differences $(P>0.05)$ among the mean concentrations of $\mathrm{Na}$ metal in the leaf samples.

Magnesium concentrations were found to be 4370 and $4273.3 \mathrm{mg} / \mathrm{kg}$ in the Secha and Karat leaf samples, respectively (Table 3 ), which was greater than the leaf samples of the Karat site. The concentrations of $\mathrm{Mg}$ were not significantly different $(P>0.05)$ in the leaf samples.

The average concentrations of calcium in the $M$. oliefera leaf samples were found to be 19026 and $18803.30 \mathrm{mg} / \mathrm{kg}$ in the Secha and Karat leaf samples, respectively (Table 3 ). Ca concentration was greater in the leaf samples of the Secha. From the statistical F-test, there was no significant differences $(P>0.05)$ in $\mathrm{Ca}$ concentration were observed among the leaf samples analyzed.

Concentration of manganese was found to be 72.37 and $76.77 \mathrm{mg} / \mathrm{kg}$ in the Secha and Karat leaf samples, respectively (Table 3 ). Mn concentration was greater in the leaf samples of the Karat. There was no Significant difference $(P>0.05)$ in concentrations of $M n$ were found between the leaf samples from the results of statistical F- 
test.

Both $\mathrm{Mn}$ concentrations were below the tolerable limit of $500 \mathrm{mg} / \mathrm{kg}$, dry weight (Council of Europe, 2002). The critical concentration of $\mathrm{Mn}$ is 300 to $500 \mathrm{ppm}$ dry weight and the estimated safe and adequate daily dietary intake in adults is $11 \mathrm{mg} /$ day (Khan et al., 2008).

Zinc, analyzed in the $M$. oliefera leaf samples was 31.87 and $21.3 \mathrm{mg} / \mathrm{kg}$ in the case of Secha and Karat, respectively (Table 3 ). The statistical F-test showed no significant variation $(p>0.05)$ between the tested leaf samples. The amounts of $\mathrm{Zn}$ were below the US Recommended Daily Allowance (RDA) which is 15 $\mathrm{mg} /$ day for males and $12 \mathrm{mg} /$ day for females and estimated maximum intake of $77 \mathrm{mg} /$ day.

Iron was determined in the $M$. oliefera leaf samples and was found to be 81.60 and $81.37 \mathrm{mg} / \mathrm{kg}$ in leaf samples of Secha and Karat, respectively (Table 3). The statistical F-test showed no significant variation $(p>0.05)$ between the tested leaf samples. Iron is an essential micronutrient required for human growth and development. The results showed that the Moringa leaves can be a good source of iron. The values are in accordance to recommended daily allowance of iron 100 to $130 \mathrm{mg} / \mathrm{kg}$ for children; $70 \mathrm{mg} / \mathrm{kg}$ for men and 120 to $160 \mathrm{mg} / \mathrm{kg}$ for women and feeding mothers (ljarotimi et al., 2013).

Concentrations of copper in $M$. oliefera leaf samples were found to be 5.10 and $3.90 \mathrm{mg} / \mathrm{kg}$ in the Secha and karat sites, respectively (Table 3 ). The greater concentration of $\mathrm{Cu}$ was found in leaf samples of Secha site. Both concentrations were below the maximum permissible limit of $40 \mathrm{mg} / \mathrm{kg}$ dry weight (FAO/WHO, 1995). Therefore, the plant has no risk. From the statistical F-test, significant differences $(\mathrm{P}<0.05)$ in $\mathrm{Cu}$ concentration were observed among the leaf samples analyzed.

\section{Metals levels in the M. stenopetala leaf samples from Sikela and Gato}

The mean potassium concentration in the $M$. stenopetala leaves samples were found to be 12247 and 14047 $\mathrm{mg} / \mathrm{kg}$ for Sikela and Gato, respectively (Table 3). There were significant differences at $(\mathrm{P}<0.05)$ among the mean concentrations of $\mathrm{K}$ metal in the leaf samples. These differences could probably be the result of plant nutrition, climate and soil conditions (Hamurcu et al., 2010).

The sodium concentration of the $M$. stenopetala leaf samples analyzed were 1293 and $1298 \mathrm{mg} / \mathrm{kg}$ for Sikela and Gato, respectively (Table 3). F-test showed that there were no significant differences at $(P>0.05)$ among the mean concentrations of $\mathrm{Na}$ metal in the leaf samples.

Magnesium concentrations in the leaf samples were found to be 4550 and $4500 \mathrm{mg} / \mathrm{kg}$ in Sikela and Gato, respectively (Table 3 ). This was greater in the leaf samples of the Sikela site. There were no significant difference $(P>0.05)$ in concentration of $M g$ between the leaf samples.

The average concentrations of calcium in the $M$. stenopetala leaf samples were found to be 18341.70 and $18230 \mathrm{mg} / \mathrm{kg}$ in the Sikela and Gato, respectively (Table 3). Ca concentration was greater in the leaf samples of the Sikela site. From the statistical F-test, there were no significant differences $(P>0.05)$ in Ca concentration were observed among the leaf samples analyzed. High concentration of $\mathrm{Ca}$ is important because of its role in bones, teeth, muscles system and heart functions. The present study show satisfactory level of $\mathrm{Ca}$ accumulation as in earlier reports Moringa leaf samples (Abdul et al., 2012).

Concentrations of manganese in the $M$. stenopetala leaf samples of were found to be 86.13 and $87.53 \mathrm{mg} / \mathrm{kg}$ in the Sikela and Gato, respectively (Table 3). Mn concentration was greater in the leaf samples of the Gato site. There was no significant difference ( $P>0.05)$ concentrations of $\mathrm{Mn}$ were found between the leaf samples from the results of statistical F-test. For medicinal plants the WHO (FAO/WHO, 1984) limit has not yet been established for $\mathrm{Mn}$. The range of $\mathrm{Mn}$ concentration in selective medicinal plants of Egypt was between 44.6 to 339 ppm (Jabeen et al., 2010). The concentration of $M$. stenopetala under the present study is in the range of 10 to $1800 \mathrm{ppm}$, indicating that all the concentration of $\mathrm{Mn}$ in the plants studied is around the normal range.

Zinc, analyzed in the $M$. stenopetala leaf samples were found to be 57.63 and $27.90 \mathrm{mg} / \mathrm{kg}$ in the case of Sikela and Gato, respectively (Table 3 ). $\mathrm{Zn}$ concentration was greater in the leaf samples of the Sikela site. The statistical F-test showed significant variation $(p<0.05)$ between the tested leaf samples. The permissible limit set by $\mathrm{FAO} / \mathrm{WHO}$ in edible plants was $27.4 \mathrm{ppm}$.

According to Jabeen et al. (2010), the range of $\mathrm{Zn}$ in agricultural products should be between 15 to $200 \mathrm{mg} / \mathrm{kg}$. Iron was determined in the $M$. stenopetala leaf samples and were found to be 80.03 and $82.30 \mathrm{mg} / \mathrm{kg}$ in leaf samples of Sikela and Gato, respectively (Table 3). Zn concentration was greater in the leaf samples of the Gato site. The statistical F-test showed no significant variation $(p>0.05)$ between the tested leaf samples. The permissible limit set by $\mathrm{FAO} / \mathrm{WHO}(\mathrm{FAO} / \mathrm{WHO}, 1984)$ in edible plants was $20 \mathrm{ppm}$. For medicinal plants the WHO (FAO/WHO, 1984) limit has not yet been established for iron. The range of iron in selective medicinal herbs of Egypt in the study carried out was between 261 to 1239 ppm (Jabeen et al., 2010). The concentration of $\mathrm{Fe}$ in the $M$. Stenopetala is around the normal range for the element when compared with the medicinal herbs of Egypt.

Concentrations of Copper in $M$. stenopetala leaf samples were found to be 3.43 and $4.13 \mathrm{mg} / \mathrm{kg}$ in the Sikela and Gato, respectively (Table 3 ). The greater concentration of $\mathrm{Cu}$ was found in leaf samples of Gato site. Both concentrations were below the maximum 
Table 4. $\mathrm{pH}$ of the soils (Mean $\pm \mathrm{SD}, \mathrm{n}=3$ ).

\begin{tabular}{ll}
\hline Sample site & $\mathbf{p H ~}\left(\mathbf{H}_{2} \mathbf{O}\right)$ \\
\hline Secha & $7.86 \pm 0.10$ \\
Sikela & $8.11 \pm 0.11$ \\
Karat & $8.16 \pm 0.17$ \\
Gato & $8.29 \pm 0.07$ \\
\hline
\end{tabular}

Table 5. Concentration (mean $\pm \mathrm{SD}, \mathrm{n}=3$, $\mathrm{mg} / \mathrm{kg}$ air dry weight) of metals in soil samples.

\begin{tabular}{|c|c|c|c|c|c|}
\hline \multirow{3}{*}{ Metals } & \multicolumn{4}{|c|}{ Metal concentration $(\mathrm{mg} / \mathrm{kg})$} & \multirow{3}{*}{$\begin{array}{c}\text { WHO permissible limit } \\
(\mathrm{mg} / \mathrm{kg})\end{array}$} \\
\hline & Secha & Karat & Sikela & Gato & \\
\hline & Soil & Soil & Soil & Soil & \\
\hline $\mathrm{K}$ & $3523 \pm 205.5$ & $1540 \pm 134.50$ & $3343.30 \pm 236.90$ & $2930 \pm 91.65$ & NA \\
\hline $\mathrm{Na}$ & $1980 \pm 87.18$ & $1623 \pm 94.52$ & $2776.70 \pm 76.38$ & $1773.30 \pm 80.02$ & NA \\
\hline $\mathrm{Mg}$ & $3606.7 \pm 66.58$ & $3533 \pm 45.09$ & $4253.30 \pm 197.60$ & $4463.3 \pm 204.29$ & NA \\
\hline $\mathrm{Ca}$ & $17210 \pm 2025.0$ & $17633 \pm 985.3$ & $17513.30 \pm 1746$ & $17340 \pm 374.03$ & NA \\
\hline $\mathrm{Mn}$ & $84.53 \pm 3.24$ & $11.0 \pm 0.10$ & $5.33 \pm 0.25$ & $29.67 \pm 3.79$ & $2000^{b c}$ \\
\hline $\mathrm{Zn}$ & $36.57 \pm 2.40$ & $68.27 \pm 8.44$ & $74.23 \pm 9.82$ & $77.87 \pm 26.23$ & $300^{\mathrm{a}}$ \\
\hline $\mathrm{Fe}$ & $20.27 \pm 2.05$ & $14.40 \pm 1.22$ & $21.0 \pm 1.87$ & $65.67 \pm 8.39$ & $50000^{b c}$ \\
\hline $\mathrm{Cu}$ & $1.27 \pm 0.15$ & $0.83 \pm 0.12$ & $1.03 \pm 0.15$ & $10.23 \pm 0.68$ & $100^{a}$ \\
\hline
\end{tabular}

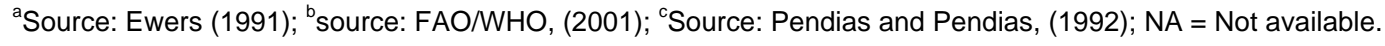

permissible limit of $40 \mathrm{mg} / \mathrm{kg}$ dry weight (FAO/WHO, 1995). From the statistical F-test, significant differences $(\mathrm{P}<0.05)$ in $\mathrm{Cu}$ concentration were observed among the leaf samples analyzed. The permissible limit set by FAO WHO for edible plants was 3.00 ppm (Jabeen et al., 2010). For medicinal herbs the WHO (FAO/WHO, 1984) limit has not yet been established for copper. In medicinal plants the permissible limit of copper set by China and Singapore were 20 and $150 \mathrm{ppm}$, respectively. The metal concentration of $M$. stenopetala was found to have below permissible limits of copper set by China and Singapore.

\section{pH of soil samples}

\section{The mean $\mathrm{pH}$ values of soils from Secha and Karat}

The mean $\mathrm{pH}$ values of the soils where $M$. oliefera was planted ranges between $7.86 \pm 0.10$ and $8.16 \pm 0.17$ (Table 4). Higher $\mathrm{pH}$ was recorded for the Karat soil sample $(8.16 \pm 0.17)$ and lower $\mathrm{pH}$ for Secha soil sample $(7.86 \pm 0.10)$. The analysis of variance showed that there was no significant difference in $\mathrm{pH}(\mathrm{P}>0.05)$. The $\mathrm{pH}$ of the soil from both sites, where $M$. oliefera planted was within the slightly alkaline range of the $\mathrm{pH}$ scale. This was in line with the findings of Anjorin et al. (2010) on the soil survey of Abuja.

\section{The mean $\mathrm{pH}$ values of soils from Secha and Karat}

The mean $\mathrm{pH}$ values of the soils where $M$. stenopetala was planted ranges between $8.11 \pm 0.11$ and $8.29 \pm 0.07$ (Table 4). Higher $\mathrm{pH}$ was recorded for the Gato soil sample $(8.29 \pm 0.07)$ and lower $\mathrm{pH}$ for the Sikela soil sample $(8.11 \pm 0.11)$. The analysis of variance showed that there was no significant difference in $\mathrm{pH}(\mathrm{P}>0.05)$. The $\mathrm{pH}$ of the soils from both sites, where $M$. stenopetala planted was within the slightly alkaline range of the $\mathrm{pH}$ scale. This was in line with the findings of Anjorin et al. (2010) on the soil survey of Abuja.

\section{Elemental compositions of soils}

\section{Metals levels in the soil samples from Secha and Karat}

As shown in the Table 5 , the mean concentrations of $\mathrm{K}$, $\mathrm{Na}, \mathrm{Mg}, \mathrm{Ca}, \mathrm{Mn}, \mathrm{Zn}, \mathrm{Fe}$ and $\mathrm{Cu}$ were 3523,1980 , $3606.70,17210,84.53,36.57,20.27$ and $1.27 \mathrm{mg} / \mathrm{kg}$, respectively in the Secha soil samples; and 1540, 1623.30, 3533.30, 17633.30, 11.0, 68.27, 14.40 and 0.83 $\mathrm{mg} / \mathrm{kg}$, respectively in the Karat soil samples. The concentrations of all metals were greater in the Secha soil samples except that of $\mathrm{Ca}$ and $\mathrm{Zn}$ which was greater in the Karat soil samples.

F-test showed significant differences $(\mathrm{P}<0.05)$ among the analyzed soil samples for the mean concentrations of all metals in except $\mathrm{Mg}, \mathrm{Ca}$ and $\mathrm{Zn}$. These differences could probably be the result of climate and soil conditions (Hamurcu et al., 2010). 


\section{Metals levels in the soil samples from Sikela and Gato}

As shown in the Table 5 , the mean concentrations of $\mathrm{K}$, $\mathrm{Na}, \mathrm{Mg}, \mathrm{Ca}, \mathrm{Mn}, \mathrm{Zn}, \mathrm{Fe}$ and $\mathrm{Cu}$ were 3343.30, 2776.70, 4253.30, 17513.30, 5.33, 74.23, 21.0 and $1.03 \mathrm{mg} / \mathrm{kg}$, respectively in the Sikela soil samples; and 2930, 1773.30, 4463.30, 17340, 29.67, 77.87, 65.67 and 10.23 $\mathrm{mg} / \mathrm{kg}$ respectively in the Gato soil samples. The concentrations of all metals were lower in the Sikela soil samples except that of $\mathrm{K}, \mathrm{Na}$ and $\mathrm{Ca}$ which was lower in the Gato soil samples. F-test showed no significant differences $(p>0.05)$ among the analyzed soil samples for the mean concentrations of all metals except $\mathrm{Na}, \mathrm{Mn}$ and Fe. These differences could probably be the result of climate and soil conditions (Hamurcu et al., 2010).

\section{Conclusion}

The data derived from proximate and mineral composition of $M$. oleifera and $M$. stenopetala leaves collected from two different agro-ecological zones indicated that the plant leaves are rich in nutrients and has potential to be used as a feed additive for human and animal. These include serving as a protein, fats, fiber, carbohydrate and mineral resource feed formulations. There was no as such significant difference in nutritional composition of the two Moringa species grown in the two agro-ecological zones. It is recommended that further investigations on vitamin, amino acid profiles and antinutritional factors of fresh Moringa leaves be carried.

\section{CONFLICT OF INTERESTS}

The authors have not declared any conflict of interests.

\section{REFERENCES}

Abdul G, Zulfaqar A, Muhammad I, Mehwish M, Saira P (2012). Estimation of macro and micro nutrients in some important medicinal plants of Soon Valley, District, Khushab, Pakistan. Afr. J. Biotechnol. 11:14386-14391.

Agena A (2009). Screening Moringa accessions for resistance to Moringa moth, Noorda blitealis walker (Crambidae: Nooridae). Ind. J. For. 32:243-250.

Al-Kharusi LM, Elmardi MO, Ali A, Al-Said FAJ, Abdelbasitand KM, AlRawahi S (2009). Effect of mineral and organic fertilizers on the chemical characteristics and quality of date fruits. Int. J. Agric. Biol. $11: 290-296$

Amaechi NC (2009). Nutritive and anti-nutritive evaluation of wonderful kola (Buccholzia coricea) seeds. Pak. J. Nutr. 8:1120-1122.

Anjorin TS, Ikokoh P, Okolo S (2010). Mineral composition of Moringa oleifera leaves, pods and seeds from two regions in Abuja, Nigeria. Int. J. Agric. Biol. 12:431-434.

Anthonia OO (2012). Evaluation of antimicrobial properties and nutritional potential of Moringa leaves in South-Western Nigeria. Malays. J. Microbiol. 8:59-67.

AOAC (1990). Official Methods of Analysis. Arlington, Virginia USA: Association of Official Analytical Chemist, Inc.
AOAC (2000). Official Methods of Analysis. Arlington, Virginia USA: Association of Official Analytical Chemist, Inc.

Armelle De SS, Melanie B (2010). Growing and Processing of Moringa Leaves. Moringa Association of Ghana.

Bosch CH (2004). Moringa stenopetala Lam. In: Grubben GJH, Denton OA (Eds.), PROTA 2: (Plant Resources of Tropical Africa/ Resources végétales de l'Afrique tropicale, Wageningen, Netherlands.

Busani M, Masika PJ, Hugo A, Muchenje V (2011). Nutritional characterization of Moringa (Moringa oleifera Lam.) leaves. Afr. J. Biotechnol. 10:12925-12933.

Council of Europe (2002). Guide Lines on Metals and Alloys Used as Food Contact Materials, Council of Europe Press.

Ewers U (1991). Standards, Guidelines and Legislative Regulations Concerning Metals and Their Compounds. In. E. Merian (Ed.), Metals and Their Compounds in the Environment: Occurrence, Analysis and Biological Relevance, 3 volume, Merian, E, Anke, M, Ihant, M and Stoeppler, M (eds.), Wiley-VCH, Weinheim.

FAO/WHO (1984). Contaminants. In codex Alimentarius, vol. XVII, Edison 1. FAO/WHO, Codex Alimentarius Commissions, Rome, Italy.

FAO/WHO (1995). Codex General Standard for Contaminants and Toxins in Food and Feed (CODEX STAN 193-1995), Vienna.

FAO/WHO (2001). (Codex Alimentarius Commission), Food Additives and Contaminants, Joint FAO/WHO Food Standards Program: ALINORM 01/12A:1-289, Vienna.

Grubben GJH, Denton OA (2004). Vegetables: Plant Resources of Tropical Africa Part 2, Foundation/Buckhuys Publishers/ CTA.

Hamurcu M, Musa Ozcan M, Dursun N, Gezgin S (2010). Mineral and heavy metal levels of some fruits grown at the roadsides. Food Chem. Toxicol. 48:1767-1770.

ljarotimi OS, Adeoti OA, Ariyo O (2013). Comparative study on nutrient composition, phytochemical, and functional characteristics of raw, germinated, and fermented Moringa oleifera seed flour. Food Sci. Nutr. 1:452-463

Jabeen S, Shah MT, Khan S, Hayat MQ (2010). Determination of major and trace elements in ten important folk therapeutic plants of Haripur basin, Pakistan. J. Med. Plant Res. 4:559-566.

James S (1995). Analytical Chemistry of Food. Glawgow, UK: Blackie Academic and Professional.

Khan SHA, Khan L, Hussain I, Marwat KB, Akhtar N (2008). Profile of heavy metals in selected medicinal plants. Pak. J. Weed Sci. Res. 14:101-110.

Mahan MR, Konan NY, Sidibe D, Coulibaly A, Ezoua P, Chatigre KO, Biego GHM (2016). Nutritive compounds from leaves of Moringa oleifera L. and beans of Vigna unguiculata W. for improvement of the meal deriving with new shoots of Borassus aethiopum M. in Côte d'Ivoire. Int. J. Environ. Agric. Res. 2:64-74.

Martin EA, Coolidge AA (1978). Nutrition in action. $4^{\text {th }}$ ed. Holt, $R$ and Wilson Co., New York.

Melesse A, Berihun K (2013). Chemical and mineral compositions of pods of Moringa stenopetala and Moringa oleifera cultivated in the lowland of Gamogofa Zone. J. Environ. Occup. Sci. 2:33-38.

Melesse A, Bulang M, Kluth $H$ (2009). Evaluating the nutritive values and in vitro degradability characteristics of leaves, seeds and seedpods from M. stenopetala. J. Sci. Food Agric. 89:281-287.

Melesse A, Steingass H, Boguhn J, Schollenberger M, Rodehutscord M (2012). Altitudinal and seasonal variations in nutritional composition of leaf and green pod fractions of Moringa stenopetala and Moringa oleifera. Agroforest. Syst. 86:505-518.

Melesse A, Tiruneh W, Negesse T (2011). Effects of feeding Moringa stenopetala leaf meal on nutrient intake and growth performance of Rhode Island Red chicks under tropical climate. Trop. Subtrop. Agroecosys. 14:485-492.

Muhammad A, Dangoggo SM, Tsafe AI, Itodo AU, Atiku FA (2011). Proximate, mineral and anti-nutritional factors of Gardenia aqualla (Gauden dutse) fruit pulp. Pak. J. Nutr. 10:577-581.

Nielsen SS (2010). Food Analysis, Food Science Texts Series. New York: Springer.

Ogbe AO, John PA (2011). Proximate study, mineral and anti-nutrient composition of Moringa oleifera leaves and potential benefits in poultry nutrition and health. J. Microbiol. Biotechnol. Food Sci. 1:296308.

Onu PN, Aniebo AO (2011). Influence of Moringa oleifera meal on the 
performance and blood chemistry of starter broilers. Ind. J. Fundam. App. Life Sci. 1:38-44.

Pendias AK, Pendias H (1992). Elements of group VIII. In. Trace elements in soils and plants. Boca Raton: CRC Press. Pp. 271-276.

Sanchez NR, Ledin S, Ledin I (2006). Biomass production and chemical composition of Moringa oleifera under different management regimes in Nicaragua. Agroforest. Syst. 66:231-242.

Sanchez-Machado DI, Nunez-Gastelum JA, Reyes-Moreno C, RamirezWong B, Lopenz-Cervantes J (2010). Nutritional Quality of edible Parts of Moringa oleifera. Food Anal. Methods 3:175-180.

Shad AA, Bakht J, Shah HU and Hayat Y (2016). Antioxidant activity and nutritional assessment of under-utilized medicinal plants. Pak. J. Pharm. Sci. 29:2039-2045.
Tetteh ONA (2008). Effects of blanching and dehydration methods on the quality of Moringa leaf powder used as herbal green tea. [Master's thesis], Kwame Nkrumah University, Ghana.

Wani SA, Shah TR, Bazaria B, Nayik GA, Gull A, Muzaffar K, Kumar P (2014). Oats as a functional food: a review. Univ. J. Pharm. 3:14-20.

Yang RY, Tsou SCS, Lee TC, Chang LC, Kuo G, Lai PY (2006). Moringa a novel plant rich in antioxidants bio-available iron and nutrients. Am. Chem. Soc. Symp. Ser. 925:224-239. 